16 Vaughan JH, Carson DA, Fox RI. The Epstein-Barr virus and rheumatoid arthritis. Clin Exp Rheumatol 1983;1:265-72.

17 Silman AJ. Recent trends in rheumatoid arthritis. Br f Rheumatol 1986;25:328-9.

18 Silman AJ. Are there secular trends in the occurrence and severity of rheumatoid arthritis? Scand $\mathcal{\gamma}$ Rheumatol 1989;79:25-30

19 Linos A, Worthington JW, O'Fallon M, Kurland LT. The epidemiology of rheumatoid arthritis in Rochester Minnesota: a study of incidence, prevalence, and mortality. Am $\mathcal{F}$ Epidemio Rochester Minnes: $111: 87-98$.

20 Dugowson CE, Bley L, Koepsell TD, Nelson JL, Daling JR. Incidence of rheumatoid arthritis in women. Arthritis Rheum 1989;22(suppl):A83.

21 Silman AJ. Has the incidence of rheumatoid arthritis declined in the United Kingdom? $\mathrm{Br}$ Rheumatol 1988;37:77-8.

22 Hochberg M. Changes in the incidence and prevalence of rheumatoid arthritis in England an Wales-1970-1982. Semin Arthritis Rheum 1990;5:294-302.
23 Laurent R, Robinson RG, Beller EM, Buchanan WW. Incidence and severity of rheumatoid arthritis - the view from Australasia. Brf Rheumatol 1989;28:360-1.

24 Buchanan WW, Laurent RM. Rheumatoid arthritis: an example of ecological succession. Canadian Bulletin of Medical History 1990;7:77-91.

25 Silman AJ, Davies P Currey HLF, Evans SJW. Is rheumatoid arthritis becoming less severe? fournal of Chronic Diseases 1983:36:891-7.

Jounal of Chrom Diseases 1

A. Australian mortality statistics for rheumatoid arthritis 1950-81 analysis of death certificate data. Ann Rheum Dis 1988;47:563-9.

27 Aho $\mathrm{K}$, Kirpila J, Wager $\mathrm{O}$. The persistence of the agglutination activation factor (AAF) in the circulation. A nine year study of twenty seven patients. Annals of Experimental Medicin 1959;37:377-8

28 Lawrence JS. Rheumatism in populations. London: Heinmann, 1977.

29 Buchanan WW, Murdoch RM. That rheumatoid arthritis will disappear. F Rheumatol 1979;6: $324-9$.

\title{
"Second line" drugs for rheumatoid arthritis
}

\section{The next generation of drugs needs more rigorous assessment}

As its cause is unknown rheumatoid arthritis is difficult to treat. The bulwark of drug treatment remains symptomatic relief with non-steroidal anti-inflammatory drugs and attempts at suppressing the disease process with "second line" or "disease modifying" drugs," including gold salts (first introduced in 1929) ${ }^{2}$; steroids $(1949)^{3}$; chloroquine $(1956)^{4}$; penicillamine $(1973)^{5}$; sulphasalazine $(1980)^{6}$; auranofin $(1982)^{7}$; and cytotoxic drugs such as cyclophosphamide, azathioprine, and methotrexate. ${ }^{89}$ Does use of these drugs, either singly or in combination, alter the prognosis of rheumatoid arthritis?

Evaluating the effects of second line drugs in a disease that is subject to relapses and remissions is difficult especially when they provide symptomatic relief and have uncertain effects on the underlying disease process. Rheumatologists use measures of disease process and outcome to evaluate the effects of second line drugs ${ }^{10}:$ measures of process consist of variables such as the erythrocyte sedimentation rate, $\mathrm{C}$ reactive protein concentration, and titres of rheumatoid factor; measures of outcome encompass various functional indices (for example, the health assessment questionnaire ${ }^{11}$ ) and radiological progression of joint damage. An important problem with these two modes of measurement is the generally poor correlation between them. Other problems are that most clinical trials monitor changes over one to two years - a relatively short time in the lifetime of the diseaseand the high drop out rate of patients being maintained with second line treatment - less than one third will still be taking their drugs two years on. ${ }^{12}$

Many published trials of second line treatment in rheumatoid arthritis have too few patients to be meaningful, a problem that can be overcome by meta-analysis. Using this approach, Clark and her colleagues have shown that over six months injectable gold improved the active joint count, functional capacity, and erythrocyte sedimentation rate by $13-30 \% .{ }^{13}$ The most common side effect was dermatitis (15\%); proteinuria occurred in only $0.7 \%$. Using a similar approach, Iannuzzi et al concluded that in 17 trials suitable for analysis only injectable gold and cyclophosphamide convincingly retarded radiological progression of disease. ${ }^{14}$ More recent data, however, suggest that sulphasalazine may also slow the appearance of new joint erosions. ${ }^{15}$ Using meta-analysis, Felson et al compared the efficacy and toxicity of six second line drugs and concluded that, apart from auranofin and antimalarials, which had a weaker effect, no significant difference existed between the efficacies of sodium aurothiomalate, penicillamine, methotrexate, and sulphasalazine. ${ }^{16}$ (Sodium aurothiomalate, however, was more toxic.) Overall, nearly one in three patients had dropped out of the trials analysed. The authors commented that at least 170 patients are required in each treatment group to give sufficient power to differentiate one second line drug from another.

What about newer treatments? Cyclosporin $\mathrm{A}$ has been fashionable, but an 18 month follow up study of 16 patients found that long term loss of renal function occurred and radiological progression was not halted. ${ }^{17} \mathrm{~A}$ recent symposium in the United States challenged the traditional therapeutic "pyramid" in rheumatoid arthritis (a base beginning with non-steroidal anti-inflammatory drugs and progressing through second line drugs to cytotoxic agents at the apex), with several participants advocating the relatively early use of combination treatment with methotrexate, gold, azathioprine, and cyclophosphamide in various permutations. ${ }^{18}$ The cost: benefit ratio of such an approach, however, may be high, and so far too few patients have been treated to establish whether combination treatment is better than the pyramid regimen. Immunotherapy with monoclonal antibodies to $T$ cell subsets and the use of cytokine inhibitors may be an advance, ${ }^{19}$ but carefully designed trials with sufficient numbers of patients, clearly defined end points, and reasonably long treatment will be required if we are to avoid the pitfalls of the past two decades of antirheumatoid treatment.

Professor of Rheumatology,

R D STURROCK

University Department of Medicine,

Centre for Rheumatoid Diseases,

Royal Infirmary, Glasgow G31 2ER

1 Hepburn B. What is a disease modifying antirheumatoid drug? $f$ Rheumatol 1986;15(suppl 16): 40-2.

2 Forestier J. L'Aurotherapies dans les rheumations chroniques. Bulletins et Memoires de la Societe Medicale des Hopitaux de Paris 1929;44:323.

3 Hench PS, Kendall EC, Slocumb CH, Polly HF. The effect of a hormone of the adrenal cortex (17hydroxy-11 dehydrocortisone: compound $\mathrm{E}$ ) and of pituitary adrenocorticotrophic hormone on rheumatoid arthritis. Preliminary report. Proceedings of the Staff Meetings of the Mayo Clinic 1949;24:181-97.

4 Freedman A. Chloroquine and rheumatoid arthritis. A short-term controlled trial. Ann Rheum Dis 1956;15:241-56.

Multicentre Trial Group. Controlled trial of D-penicillamine in rheumatoid arthritis. Lancet 1973;i:275-80.

6 McCarthy B, Amos R, Durham S, et al. Sulphasalazine in rheumatoid arthritis. BMf 1980;280 442-4.

7 Katz WA, Alexander S, Bland JH, et al. The efficacy and safety of auranofin compared to placebo in rheumatoid arthritis. F Rheumatol 1989;9(suppl 8): 173-8.

8 Luqhami RA, Palmer RG, Bacon BA. In: Brookes PM, ed. Slow-acting antirheumatic drugs and immunosuppressives. London: Baillière Tindall, 1990:595-619.

Tugwell P, Bennette K, Gent M. Methotrexate in rheumatoid arthritis. Ann Intern Med 1987; 107:358-66.

10 Scott DL, Dacre JE, Greenwood A, Treasure L, Huskisson EC. Can we develop simple response criteria for slow acting antirheumatoid drugs? Ann Rheum Dis 1990;49:196-8.

11 Fries JF, Spitz P, Kraines RG, Holman HR. Measurement of patient outcome in arthritis. Arthritis Rheum 1980;23:137-45.

12 Thompson PW, Kirwan JR, Barnes CG. Practical results of treatment with disease-modifying antirheumatoid drugs. Brf R Reumatol 1985;24:167-75.

13 Clark P, Tugwell P, Bennett K, Bombardier C. Meta-analysis of injectable gold in RA. $\mathcal{J}$ Rheumatol 1989;16:442-7.

14 Iannuzzi L, Dawson N, Zein N. Does drug therapy slow radiographic deterioration in rheumatoid arthritis. N Engl f Med 1983;309:1023-8.

15 Pullar T, Hunter J, Capell HA. Effect of sulphasalazine on the radiological progression of rheumatoid arthritis. Ann Rheum Dis 1987;46:398-402.

16 Felson D, Anderson J, Meenan R. The comparative efficacy and toxicity of second-line drugs in rheumatoid arthritis. Arthritis Rheum 1990;33:1449-61.

7 van Rythoven AW, Dysmans B, The HSG. Long term cyclosporine therapy in RA. I Rheumatol
(1) 1991;18:19-23.

18 Jaffe IA. Combination therapy of RA-rationale and overview. I Rheumatol 1990;17(suppl 25): 24-7.

19 Panayi GS, Lanchbury JSS, Kingsley G, eds. First international symposium on the immunotherapy of the rheumatoid diseases. Brf Rheumatol 1991;30(suppl 2):3-9. 